\title{
A Cross-Disciplinary Project-Based Learning to Raise Indonesian Students' Awareness of Natural Disasters
}

\author{
Anna Marietta da Silva ${ }^{1}$, Helnywati ${ }^{2}$ \\ ${ }^{1}$ Atma Jaya Catholic University of Indonesia, ${ }^{2}$ YPK School, Indonesia \\ anna.silva@atmajaya.ac.id
}

First draft received: 31 May 2020 Date Accepted: 20 Nov 2020 Final proof received: 31 Jan 2021

Abstract
The present study aims at raising young students' awareness of natural disasters through a cross-
disciplinary multimodal project-based learning method using Vygotsky's (1986) socio-cultural approach. An
Art project was carried out by $2^{\text {nd }}$ grade students of one private bilingual school in Jakarta. The project, which
was a group work, included discussing which objects that could save lives from the disaster, drawing the
objects and presenting the work in front of the class. All discussions and presentations were audio recorded.
The objects and the recording were then analysed to identify students' knowledge about surviving from three
common natural disasters in Indonesia, i.e., earthquake, tsunami, and volcanic eruption. The findings
indicate that the students have initial knowledge about how to survive from the disasters, but their literacy on
disaster mitigation is still low. It is recommended that literacy on natural disasters should be part of the
curriculum and implemented consistently.
Keywords: multimodality; natural disaster awareness; project-based learning; socio-cultural approach to
learning

\section{INTRODUCTION}

Indonesia is one of the world's most disaster-prone countries (UNDP, 2018). Its physical geography makes it liable to natural disasters such as earthquakes, volcanic eruptions and tsunamis (Kusumastuti et al., 2014). Hence, raising Indonesian students' awareness of natural disasters is important. Disaster is defined as "a crisis that can cause largescale damage to a community and hinder its ability to discover" (Lee \& Lee, 2019, p. 311). There are two types of disasters, natural disasters such as earthquakes, volcanic eruptions, and tsunamis, and social disasters, for example fires, flood, infectious diseases, and traffic accidents. The two types of disasters affect both the physical and mental health of the victims. Therefore, disaster awareness and management are needed to avoid victims and hazards, especially in places where natural disasters repeatedly occur.

Indonesia lies in the Pacific Ring of Fire and is located at the joining area of four tectonic plates (Siagian et al., 2014). Indonesians, especially children, should be aware of the risks of living in a disaster-prone area and have knowledge on how to cope with natural disasters. Low awareness of natural disasters might result in deaths, insufficient food supply, and infectious diseases, and mental problems such as traumas, abuses, abandonment (Kousky, 2016). Such an awareness is not only part of individuals' knowledge, but also a means of survival. Therefore, Indonesian children should know much about the types of potential disasters, how to cope with them, how to minimize risks, and how to be resilient.

Schools play an important role in providing education about natural disasters mitigation (Seyle et al., 2013). Schools and the community should provide learning experience, including that related to natural disasters. In addition, schools and other public places such as hospitals, government offices, mosques and churches often become meeting points for people directly affected by disasters. Consequently, formal education of coping with both natural and social disasters should be initiated by schools. Research has shown that when students are actively involved in a disaster education program, they have better knowledge about natural disasters and the risks and are more prepared to cope with them (Adiyoso \& Kanegae, 2012). Hence, a curriculum-based disaster 
education program is urgently needed and the implementation may be cross-disciplinary.

Cross-disciplinary refers to "an activity that involves two or more academic disciplines" (Szostak, 2015). It reflects "connections, interrelations and interactions between different fields of knowledge" (Avraham, 2006). Using cross-disciplinary approach, teachers and students learn to comprehend a huge amount of information better. Cross-disciplinary approach also aligns with the current curriculum in Indonesia, the Curriculum 2013, which implements thematic approach at primary level. In the new curriculum, similar to cross-disciplinary, the teaching and learning process involves more than one discipline (The Indonesian Ministry of Education Regulation No. 22 Year 2016). The approach also encourages teachers to produce an alternative method of learning that involves both theories and practices from different points of views. Students may get a wider perspective on a specific topic that is learned (Penttilä et al., 2014). However, teachers need to carefully design the lesson so that the learning goals can be achieved. Although this approach is suitable for higher education, it does not necessarily mean that it cannot be adopted for the lower level.

One of the methods to implement crossdisciplinary approach is the project-based learning (henceforth, PBL) because in PBL, students will "learn by doing and applying ideas" (Krajcik \& Blumenfeld, 2012, p. 317). In PBL students have the opportunities to learn from real-world professional activities although in the context of lower-level education which may not always be applicable. What can be adopted is the construction of new knowledge by actively using and working on their ideas in the forms of inquiries which are followed by explorations, analyses, discussions and trials of the ideas (Krajcik \& Blumenfeld, 2012; Lee, 2005). This should be adjusted to the students' age, background knowledge and other relevant aspects. In addition, PBL has been appreciated for enabling students to develop several skills including decision-making, creative thinking and problemsolving (Beckett \& Slater, 2018). Research has reported the adoption of $\mathrm{PBL}$ in EFL or ESL adult classrooms, particularly with regard to learning through technology (for example Beckett \& Slater, 2018; Mali, 2017; Marwan, 2015).

Earlier technologies, such as TV news broadcasts, have been used as teaching and learning media. Previous studies have indicated students' positive responses towards the use of news broadcast for learning English (e.g., Evans, 2006; Abdul Razak \& Babikkoi, 2012; Moglen, 2014). Evans (2006) identified several reasons why TV news is suitable to be implemented in English classrooms, which include its short duration, authenticity, richness, and current issues. She also gave some suggestions on how to integrate reading, writing, listening and speaking with the use of news broadcasts (BBC, CNN, and $A B C$ ) in teaching. Similarly, Abdul Razak and Babikkoi (2012) proposed the use of news broadcast as part of English learning strategies in order to motivate and establish positive attitudes toward the language. In that regard, Moglen (2014) presented projects students had to carry out after watching the news broadcast, such as oral presentation and written composition in which they had to analyse the presence of bias, concentrate on one particular story, and examine the effect of the news broadcast to people's impression of the country.

In addition to radio and TV news-broadcast, video has proved to be able to help students develop their English skills. Video is not only useful for teaching but also for learning (Donaghy, 2014). Creating video, students have many opportunities to learn English from various sources that they can find, such as online dictionaries, films, storybooks, and other texts. From those sources, they can have another set of learning experience, i.e., video creation in which they have to actualize their ideas by using a series of pictures, words, sounds, voice and other tools.

Realizing that building and increasing awareness of natural disasters can reduce risks of the disasters to people, especially young children, researchers have focused their attention to the role of education institutions to take part in developing such an awareness. Amri et al. (2017), for instance, assessed the implementation of disaster risk reduction in three groups: (1) school personnel including teachers, administrators, principals, (2) government agencies that focused on promoting the implementation of DRR, and (3) students. The methods and findings presented here are those related to the third group, the students. A set of questionnaires for the students was designed to evaluate their interest and knowledge on disaster risk reduction, which included fire prevention and safety, flood preparedness and response, and hygiene behavior. The research revealed some interesting findings. First, the subjects knew which natural disasters could directly affect their houses and schools (e.g., floods, fires, earthquakes) and those that could not (e.g., tsunamis, volcanic eruption, landslides). Second, most of them had sufficient knowledge of how to be safe and calm in an emergency, but also felt afraid when reminded of disasters. Third, they wanted to get more information on how to save themselves, to reduce their fear as well as to protect their families when disasters happen.

Similarly, Mustadi and Atmojo (2020) investigated Disaster Information Literacy (henceforth, DIL) of Indonesian primary students in Bantul, Yogyakarta, which is located in one of earthquakeprone areas in Indonesia. Through an experimental study, the researchers measured the level of students' DIL, i.e., "knowing the source of disaster information, evaluating disaster information, organizing disaster information and utilizing and delivering disaster information" (Mustadi \& Atmojo, 2020, p. 668) in terms of mitigation, adaptation and responsibility skills that were learned through SETS- Science, Environment, Technology and Society-based disaster learning adapted into the primary school students 
thematic learning. They found that SETS-based learning could develop students' disaster literacy.

In terms of the inclusion of disaster literacy into schools, Mufit, et al. (2020) conducted a textbook analysis particularly physics textbooks for secondary school students. The textbook analysis showed that disaster literacy, the indicators of which were ability to link physics learning material with appropriate disasters and incorporate disaster mitigation in physics learning, was not included despite the fact that natural phenomena and Physics are interwoven.

On the oher hand, Sözcü (2020) proposed a natural disaster literacy curriculum model. He pointed out that a natural disaster literacy covers not only knowledge about, but also attitutudes and behaviors against natural disasters. Theefore, a natural disaster literate person is expected to have basic knowledge of the principles of nature and natural disaster systems and will be able to evaluate relevant information so that he can be relied on to make decisions with regard to natural disasters because he can predict the effects and can take necessary mitigation socially and culturally. In the proposed curricullum, the following skills should be developed: geogrpahical obersvation, fieldwork, mapping, spatial analysis and social participation.

With regard to cross-disciplinary teaching for raising young students' awareness of natural disasters, Haring, Sorin and Caltabiano (2018) argued in favor of the use of poem to introduce Australian primary school students to natural disasters, in particular cyclone. In Australia, disaster education has become part of the curriculum. The poem was based on a local myth about cyclone and it was integrated with musical terms which the students have been familiar. Other poems about natural phenomena can also be used to make students familiar with other disasters. In response to the poems, students were asked to answer comprehension questions and do artbased activities like drawing a comic strip or pictures relevant to the theme. The previous studies have demonstrated how primary schools were actively involved in promoting awareness of natural disasters. However, the integration of the theme into crossdisciplinary learning in Indonesian schools has not received much attention.

Considering the needs of developing awareness of natural disasters, the benefits of cross-disciplinary approach and PBL approaches, and the limited studies that focus on the integration of the previous three points, this rese (Mufit, Asrizal, Hanum, \& Fadhilah, 2020)arch proposes two project-based learning activities through a cross-disciplinary and cross-level project-based instructions to raise young students' awareness of earthquakes, volcano eruptions and tsunamis through news-broadcast (CNN 10) viewing, followed by video and drawing for $6^{\text {th }}$ and $2^{\text {nd }}$ graders, respectively. At the end of the second project, we investigated the $2^{\text {nd }}$ grade students' knowledge and awareness about the natural disasters; we were guided by these two questions: (1) what tools do the students draw to save them from the natural disasters? and (2) what do the students' works reveal about their awareness on the natural disasters? The goal of this study is to raise students' awareness of natural disasters in Indonesia through multimodal learning activities and cross-disciplinary learning involving Arts, Social Science, and English language. It was decided to ask students to draw tools because tools mediate human beings with the world (Vygotsky, 1986) including to knowledge about natural disasters. Another practical reason is that tools are abstract objects that children can easily draw. The study is expected to contribute to the existing literature on cross-disciplinary approach learning as well as to give insights about PBL to subject and language teachers in primary schools and to promote early social awareness of the common natural disasters in Indonesia.

\section{METHOD}

The case study took place in a private school in South Jakarta, which uses a combination of Cambridge and national curriculum with English as a medium of instruction. The subjects were one class of $6^{\text {th }}$ grade and $2^{\text {nd }}$ grade students. The integrated subjects are Arts, Social Science and English. The second author was the homeroom teacher of the $2^{\text {nd }}$ grade. She taught Arts and Civics for the $2^{\text {nd }}$ grade and Arts for the $6^{\text {th }}$ grade. For the $2^{\text {nd }}$ grade, she integrated the theme Natural Disasters, which was taught in the Social Science class, to her Arts class and for the Art class in the $6^{\text {th }}$ grade, she assigned her students to make a video to raise their awareness of natural disasters in Indonesia, particularly tsunami, earthquake and volcano eruption.

In the two classes, she showed students news about natural disasters. She used videos from CNN 10 (and other sources) that covered news about earthquakes, volcanic eruptions and tsunamis in Indonesia or other areas. CNN 10 provides real news videos in relatively simpler English because the videos are specially designed for students. The information broadcasted in the videos was relevant to current situations. The second author mainly used videos taken from CNN 10 for discussing the most current events that are relevant to the syllabus as well as National Geographic documentary videos for supplementary materials.

There were two projects carried out. The first was video making that was done by the $6^{\text {th }}$ graders and the second project was drawing and presenting the drawing by the $2^{\text {nd }}$ graders. All projects were done in groups of 3 during the Arts class. The video made by the $6^{\text {th }}$ graders was used as one of learning materials for the $2^{\text {nd }}$ graders. During the drawing activities, the students, working in groups of three, discussed the tool(s) to draw and their function(s). After they finished drawing, there were asked to present the result in front of the class. All the group discussions and presentations were audio-taped, transcribed, and coded thematically (Creswell, 2007). 
The recording was used to help the authors clarify any tool that was not drawn clearly and the function of the objects. To answer the first and second research questions, Coates' (2002) study design was adapted. In the study young children (aged seven) had a discussion prior and during the drawing.

It is believed that drawing is able to facilitate the young students to communicate what they have in mind in a more concrete way because "they are not only able to see what they are thinking, they are also able to play around with and transform their ideas" (Brooks, 2009, p. 319). It has been widely accepted that at young age, children are able to understand abstract objects like concepts and drawing can help them gain more understanding of the concepts gradually. The drawing assignment was adapted from Grapin's (2019) study in which the students were not only asked to draw object(s), but also to discuss it in a group and present it afterwards. The entire process of drawing as a meaning making was based on Vygotsky's (1986) sociocultural approach to learning.

\section{Procedures of the classroom instructions for video-making}

Learning activities were designed based on CNN10 student news broadcast on October $17^{\text {th }}, 2017$. The main task in this activity is to get the students to create a video that raises global awareness of issues around disasters. The language focus was the use of appropriate English phrases or collocations. The required content and level of complexity of the video can be adjusted to the level of students' language proficiency. The following are the classroom instructions for the video making and for craft making.

The entire activities were divided into three phases: pre-task, task cycle, and post-task (Richards and Rodgers, 2014). In the first phase, the teacher stated the main learning objective(s) clearly prior to the lesson i.e. to have discussions about a newsbroadcast and to create a campaign video. That way the students were given an opportunity to know the expected outcome(s) as well as to prepare themselves from the beginning. Next, the teacher showed a series of pictures related to or reflect the theme of CNN 10 while inviting students to give comments on the pictures so that they could activate their schemata to the target topic. Alternatively, teacher showed several headlines of online and/or printed news about current natural disasters in Indonesia or other places in the world.

Afterwards, the teacher provided a glossary of specific terminologies which appeared in the CNN 10 (October 17 $17^{\text {th }}, 2017$ edition). Otherwise, the teacher directly proceeded to the instructions on what the students had to do while watching the news, i.e., noting down things that interest, disturb, provoke, surprise, wonder, sadden or intrigue them upon watching the news. For these pre-task activities, the teacher had the option to provide the glossary, to use subtitle, and/or to show the news more than once depending on the students' language proficiency. Figure 1 illustrates the pre-task.

\section{Figure 1}

Pre-task activities

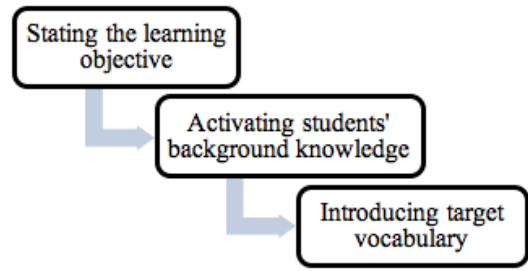

In the task phase (see Figure 2), there were five main activities, i.e., watching the video, discussing the video, learning the concept of the video, planning and making a campaign video. In the first phase, the students watched the CNN 10 in which they were shown the tsunami that happened in Japan. While watching the video, the students wrote how they felt about the incident. The students could also draw the words that expressed their own feelings upon seeing the news-broadcast. Those activities might show how deep students comprehend the news and how sensitive they were towards the incidents reported.

In the second stage, the students had a discussion in groups of three or four. The teacher facilitated the discussion. They shared and discussed the items that they wrote down or drew. They could relate the event with similar incident(s) that have happened locally. At the time when the study was conducted, there were two big natural disasters that had just taken place in Indonesia, i.e., a series of earthquakes in Lombok Island in July 2018 and another series of earthquakes in Palu, Central Sulawesi in September 2018. The goal of the discussion was to raise the awareness on the importance of appropriate community preparation and responses toward natural disasters with regard to the victims, effects of the disaster and disaster management. During the discussion, the teacher purposively introduced the target language focus (e.g., phrases, collocations, specific vocabulary) to the students.

In the third step, the teacher evoked the students' feelings towards the effects of the earthquakes and tsunamis in Lombok and Palu. She highlighted the importance of community awareness of anticipation and responses to such natural disasters. In that regard, she then invited students' opinion on doing some actions that they and their friends could do. Then, she requested the students to make a campaign video around one of the following themes: (a) knowledge about earthquake, tsunami or volcano eruption, (b) anticipating the three disasters, or (c) charity for the children victims of the disasters

Next, the teacher gave a brief explanation on several things that students had to do in their groups: 
a. choosing the theme and sub-theme (e.g., reading signs of nature, being alert and sensitive, doing some charity works)

b. determining the purpose (e.g., be cautious, be faithful, be smart, be resilient, be aware and care about others)

c. creating a storyboard (in which they had to use appropriate collocations, phrases, words) including choosing or making appropriate pictures, sounds, fonts and font colours

d. reading news, watching films or using other sources to make the video

e. listing the sources from which they obtained pictures, sounds, news, etc. for their video

f. reading and following the rubrics, which includes clarity and depth of the message, appropriate use of vocabularies including word choice, collocations, phrases, meaning and harmonious use of pictures, sounds, words and duration, ethics and task division.

In the fourth phase, the students made plans for the video in their groups. The teacher highlighted that with regard to ethics, students had to select only registered and reliable sources, such as reputable (online) newspaper, TV station, magazines as well as online websites. She also guided students to differ which information was true and which was not. The purpose of obtaining the correct information from the registered sources is to train them to select and be critical to the information they get. They also learned to read simple and relevant texts purposively. In addition, they had to list and report all sources they use for their video, e.g. (online) newspaper articles, other news-broadcasts, websites, blogs, and personal communication. Furthermore, concerning the task division, the teacher explained that students learned several soft-skills such as working collaboratively including managing tasks and time appropriately, negotiating ideas, controlling their ego and domination, and being creative.

In the fifth stage, the students created the video. The video may consist of a series of pictures, words, and sounds. It may also present a film in which students play roles. The process was done in and outside the classroom, guided by teacher or parents and siblings.

\section{Figure 2}

Main tasks

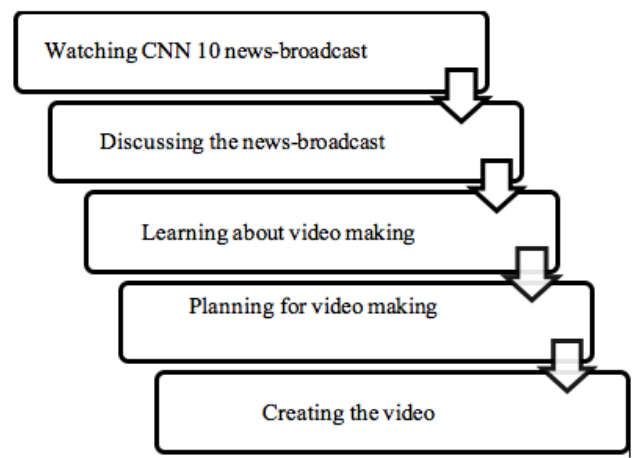

Procedures of the classroom instructions for the drawing

This stage followed the video-making by the Grade 6 students. In the first phase, the Grade 2 students watched the same CNN-10 news broadcast about an earthquake, as well as other videos about tsunami and a video made by the Grade 6 students about the volcanic eruption. In the second phase, the students worked in groups of three and discussed the videos under the teacher's guiding questions, e.g.

a.What was the video about?

b.What did you feel when watching the video?

c. What would you do if you were there?

d.What are the risks caused by the three natural disasters?

e.What would you do to make other people realize the risks?

All the discussions were audio recorded. In the third stage, the teacher elicited new words students learned from the news-broadcasts. In the fourth stage, the students discussed and drew the tools to survive from one of the three natural disasters mentioned above. In the last stage, the students described the tools and how they could save them from the natural disaster in classroom presentations, which were also audio recorded (see Figure 3 ).

\section{Figure 3}

The craft-making procedures

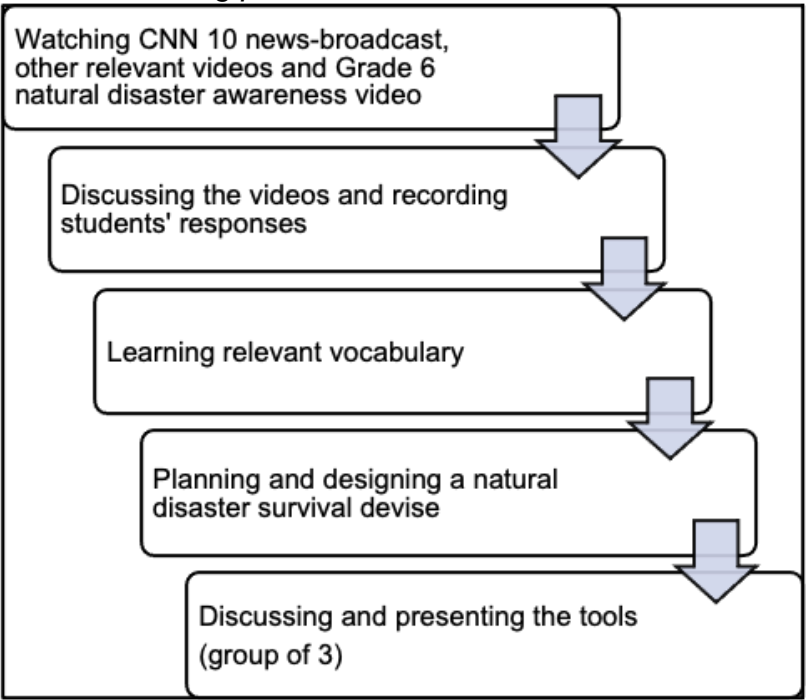

\section{RESULTS AND DISCUSSION}

The answer to the first research question was obtained from the students' drawing as well as the recorded group discussions during the drawing activity and presentation. The students were divided into three groups: (1) the earthquake group, (2) the tsunami group and (3) the volcano group. Each of the group had to discuss and draw one tool to help them survive from each of the disaster. During the drawing process, they were scaffolded by the second author who acted as a facilitator, reminder as well as time-keeper during the activity. The earthquake group drew and presented 
a plane-like vehicle that can fly and load around five persons, called the Emergency Aircraft. The vehicle is user-friendly because everyone can drive it. The tsunami group created a flying and surfing carhelicopter named 'Tesla' (which is a brand of a famous, sophisticated and expensive car). The volcano group made a device that would be fit before the volcano erupts, i.e. a shelter- like bunker.

The Emergency Aircraft (henceforth, EA) in Figure 4 was inspired by Noah's Ark as told by one of the group members. The students included the word emergency to the word aircraft although the picture resembles a helicopter. In addition, while it is written aircraft, because of the emergency state, the vehicle did not provide a lot of seats although in the discussion some students wanted to put a hundred seats. From the group discussion, it was stated that the machine and exhaust pipes will enable the EA to fly without a proper runway. For this group, the idea of drawing the EA did not come smoothly (see Excerpt 1); it came after the teacher's scaffolding (see Excerpt 2) that has made the students realize the importance of leaving the affected place as soon as possible in a vehicle that can fly so they will not feel or get affected by the earthquake as shown in their presentation notes (see Figure 5). This point will be discussed further in the next section.

\section{Figure 4}

The emergency aircraft

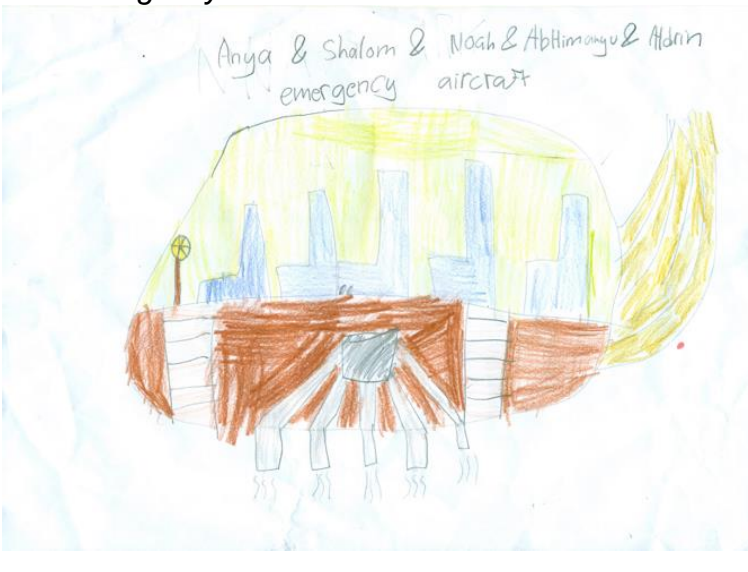

\section{Excerpt 1.}

Student C : So when the earthquake happen[s]

we can make a underground tunnel... : What's the differen[ce] then? What's the (different result) at the end? It's originally-

Student B : Uh...

Student A : It's (the idea)!

Student B : What if we make a bunker?

\section{Excerpt 2.}

Teacher

Student C

Students A

Teacher

: Think about something. What is the danger of having earthquake? Because those...

: Buildings (fall).

: Buildings will break.

: And then? How do you help yourself to be safe... when the everything is falling on... (itself)?

Teacher : Can you feel the earthquake if you're flying? ...

Student B : What about an airplane?

Teacher : Airplane needs a runway.

Student A : Wait! We $(\mathrm{xxx})$...

Teacher : No, (I'm telling you) the facts. Airplane needs a runway. The runway tracks, can you fly?

Student B : How about... How about a helicopter?

\section{Figure 5}

The Earthquake group presentation notes

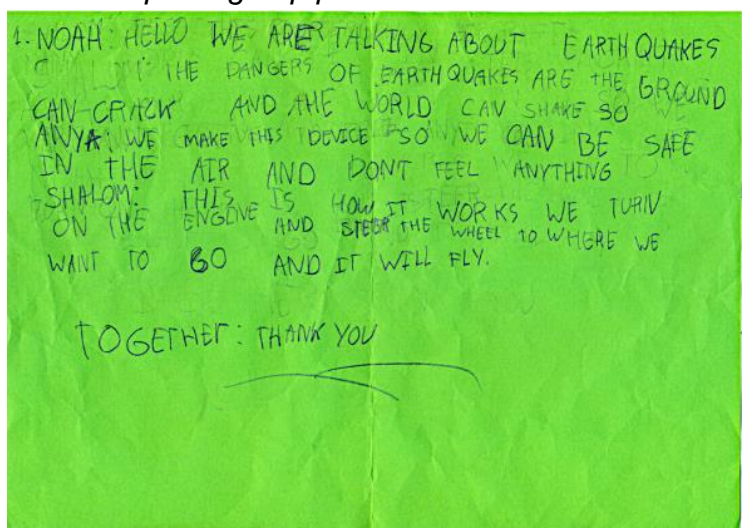

The tsunami group's object in Figure 6 was a flying car called Tesla. Different from the earthquake group, this group did not need a long time to decide that they would draw an object that can take them as fast as possible from the ground (see Excerpt 3). Another difference was the drawing of other objects in addition to the flying Tesla, including a headphone and a microphone which were very limitedly discussed during the drawing. However, in the presentation notes, the group wrote that they are properties for giving warning to people about the disaster (see Figure 7). The group also drew the sun, which may indicate that the natural disaster happens during the day. Still, another distinction is the drawing of pizza, which represents the basic needs. The initial decision to draw food was confirmed by the teacher (see Excerpt 4). In addition, there were other animate beings drawn: human and animals (cat and snake). On the bottom right, they drew a big container with water inside and a life-jacket for the person who is still on the ground. This picture presents a more complete 
life-saving act in comparison to the of the Earthquake group. The students in this group, through their contextual imagined flying car, showed that they were also aware of the urgency of leaving the affected place very soon as shown in Excerpt 3 and in the presentation notes in Figure 7. As Coates (2002) pointed out, children's drawing and their narratives can show their level of comprehension about or relevant to the objects they draw. It is highly probable that the tsunami Group has a more comprehensive awareness of life saving acts (as shown in the variety of objects they drew) than the earthquake group.

\section{Figure 6}

The flying 'Tesla'

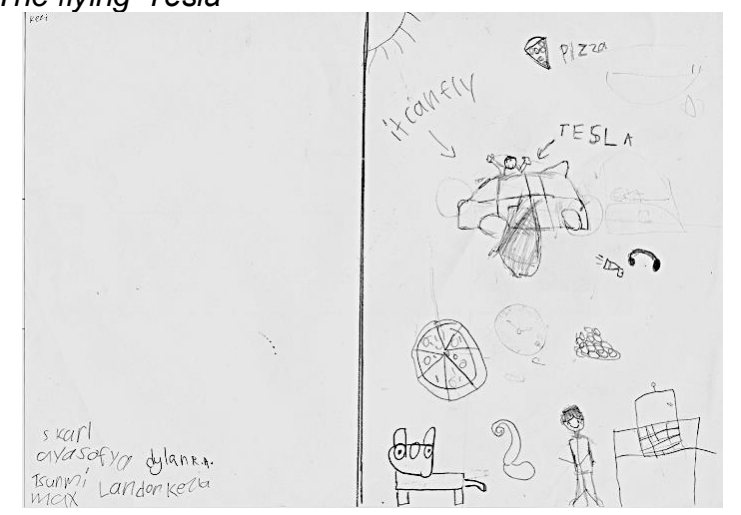

\section{Excerpt 3.}

Teacher Student E

: Why Tesla is good for tsunami?

Student D

:Because... Because (xxx). Because the Tesla $(x x x)$.

Teacher

: Oh, or we can go up the...

Teacher

: Eh, Tesla $(x x x)$ or the one that can fly?

Student G

Student D
: Tesla, the up $(x x x)$, someone's going up, right?

: You could escape the $(x x x)$.

\section{Figure 7}

The presentation notes about the flying 'Tesla' from the Tsunami group

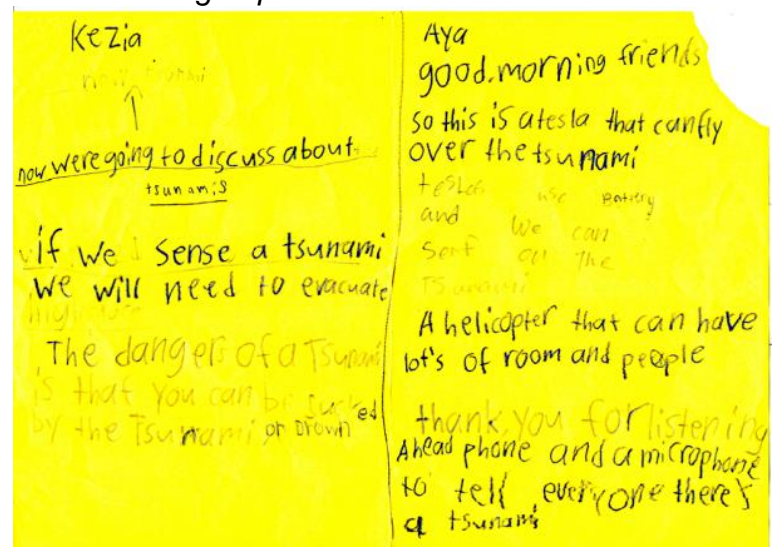

\section{Excerpt 4.}

$\begin{array}{ll}\text { Student E } & \text { : No... We're drawing food! } \\ \text { Teacher } & \text { : Huh? } \\ \text { Student E } & : \text { Food. } \\ \text { Teacher } & \text { : What do you mean? } \\ \text { Student E } & \text { : Food. } \\ \text { Teacher } & \text { : Food? } \\ \text { Student E } & : \text { (xxx) that is chicken nugget (that is) } \\ & \text { supermarket then buy it. } \\ \text { Teacher } & \text { : So you need to... get prepared with } \\ & \text { that. }\end{array}$

The volcano group drew a bunker-like shelter that was built on the ground (see Figure 8). Yet, the shelter also functioned as a path to move the people to another village that was not affected by the volcanic eruption. The bunker-like shelter was inspired by the back of a turtle (see Excerpt 5). At first, the group imagined that people can live in the device to avoid them from the larva. Nevertheless, because the teacher reminded the strength of the device against the larva, the group decided to draw the device with two entrances under the ground, which would be connected to an underground path that people can pass to go to a safer place (see Excerpt 5 and Figure 9).

Figure 8

The emergency shelter 


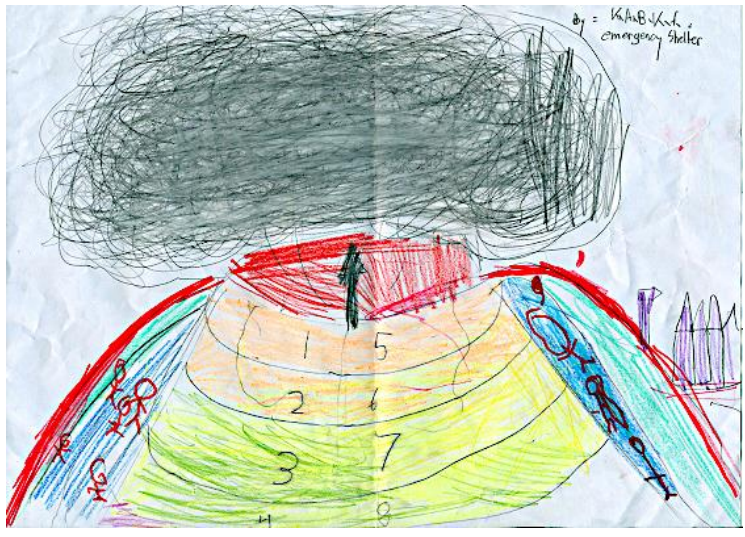

\section{Excerpt 5}

Student $J$

Student K

Student J made $(x x x)$ pathway like that. Pathway.

Student J

\section{Figure 9}

We make... something's (turtle)...

: Uh huh?

: So we wrap it around... So we wrap it around the volcano, once it explodes, it will like the- like a crane, but it's stuck- stuck inside. So when the volcano drives up, then umm... uh, it becomes, (yeah), non lava comes up.

Teacher

: . . . Remember, time is important! So when that happen[s], you need to... that device should be able to save you quickly.

: (Right here)... A dead end, and then they see... wait here... they get out when the volcano is about erupting, because they're going under the rock, you know? Which can be a little bit dangerous. So... You have to go two ways... (xxx).
Student $J \quad$ : Yeah, people who are $(x x x)$. So we

The presentation notes about the emergency shelter from the Volcano group

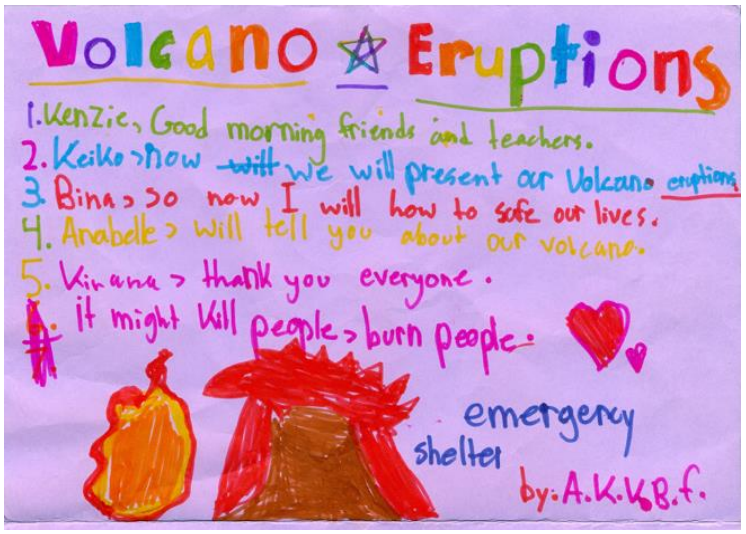

\section{Discussion}

Although the drawings were imaginary (in line with the level of the young students' knowledge and understanding), they lend a support to Brook's study (2009, p. 324) which suggests that "the process of drawing can help with the processing of ideas and the movement towards higher levels of thinking." In the present study, the students' drawings that were created through the process of group discussion and teacher's scaffolding have shown a visual thought (Brooks, 2009), i.e., evidence of their abilities to process what it meant to save a life from natural disasters through the object they drew as well as identifying the functions of each object. The drawings and the presentation may indicate an unfinished process of a gradual understanding of (hence, having a proper comprehension is crucial) what each natural disaster means, its effect to the living beings and the appropriate responses that should be taken immediately by children at their age. The complexity of the drawings as shown in Figures 6 and 8 reveals some facts about the complexity of live saving in big disasters like tsunami and volcanic eruption, such as what to do first, which should be saved first, where to go and what to bring, which may have not be fully understood by the students unless they have been fully informed of the disaster mitigation, which leads to the discussion of the second research question.

On the one hand, there were two initial issues about natural disasters that students realized, i.e. the danger of the natural disasters and the evacuation. All of the objects that the students drew as a result of the group discussions and teacher's scaffolding were things that can take them and others far away from the effected places although they are imaginary objects. That way students gave a new meaning to each of the object drawn: the aircraft and the car were not only used for transporting people and objects, but also for saving lives. Similarly, a bunker is not only a place for a protection. It can also facilitate people to move to 
another place. It is clear that the students have used "drawing as a meaning-making tool" (Brooks, 2009, p. 326). The multimodal activities have mediated the students (Vygotsky, 1986) to know more about what to do in order to save their lives should a natural disaster take place.

On the other hand, the discussions in the earthquake and volcano groups showed that they had not been fully aware of the danger of each natural disaster if they were not scaffolded by the teacher. For example, the first three minutes of the discussion of the earthquake group during the drawing were spent for discussing an underground tunnel and a bunker to save lives from an earthquake as indicated in Excerpt 1 , indicating students' limited knowledge about what an earthquake is. Without the teacher's scaffolding as shown in Excerpt 2, the group may not think about drawing an object that can move them away from the affected place. The data have displayed students' limited knowledge on the disaster literacy, particularly in evaluating and using information about natural disasters to save themselves (although the context of the present study is imaginary) (Mustadi \& Atmojo, 2020; Sözcü, 2020)..

Hence, it is crucial to include knowledge about natural disasters that commonly take place in Indonesia into the curriculum (nation-wide) including to expand the coverage of disaster-safe schools project (Amri et al., 2017). As Mustadi and Atmojo (2020) pointed out that students with disaster literacy would not only know the basic concept the natural disasters, but also the mitigation and self-adjustment should they experienced the disaster themselves. In a similar vein, Sözcü (2020) higlighted the principle knowledge of nature and natural disaster systems and their effects as well as social and cultural mititgation as indicators of the disaster literacy. Students, then, need to be informed that life-saving is the most crucial aspect. Therefore, they need to have high sense of urgency in giving the first required responses to any natural disasters. They should be made aware that the effects of the three natural disasters can be very devastating to both animate and inanimate objects, which is why a mitigation is vital. Seyle et al. (2013) argued that school is one of the parties responsible for providing a proper education about how to mitigate a natural disaster. Therefore, the Ministry of Education should include disaster literacy into the curriculum (Mustadi \& Atmojo, 2020). Together with other authorities, the Ministry and schools should conduct well-planned and well-designed campaigns on natural disasters at school so that students are prepared with all things necessary to help them face the disasters, whether or not it will directly affect them (Adiyoso \& Kanegae, 2012). As a matter of fact, the effects of a disaster do not only take place when it happens, but also when it ends. It is essential to make students realize that they have their own roles in the mitigation.
To sum up, we have shown that a subject-content teacher can develop a multimodal project-based learning between Art and Social Science in an English as a Medium of Instruction context to raise the students' awareness of natural disasters that commonly happen in Indonesia (Haring et al., 2018). Students can learn from a variety of modes, e.g., video broadcast, group discussion, images, oral presentation. The input they receive can assist them to produce new knowledge. As an alternative to drawing, older students could be guided in other multimodal projects (Diamantopoulou, 2008), such as making a campaign video for their friends to help them realize the danger of disasters and make necessary anticipation, creating a map for evacuation (Mustadi \& Atmojo, 2020), proposing a plan for helping the victims. We realize that this small-scale project has several limitations in terms of the research approach, particularly the application of disaster literacy model, limited number of subjects and period of investigation. Therefore, we recommend that larger research should involve more participants with a measured outcome of students' literacy on natural disasters.

\section{ACKNOWLEDGEMENT}

We would like to thank the Center for Research and Community Service of Atma Jaya Catholic University of Indonesia for funding this research, our studentresearch assistant, Pasayudha Dhaneswara as well as the reviewers of this article.

\section{REFERENCES}

Abdul Razak, N. Z., \& Babikkoi, M. A. (2012). Integrating the broadcast media in teaching strategies of Learning ESL in Malaysia. Journal of Education and Practice, 3(7), 1-8.

Adiyoso, W., \& Kanegae, H. (2012). The effect of different disaster education programs on tsunami among schoolchildren in Aceh, Indonesia. Disaster Mitigation of Cultural Heritage and Historic Cities, 6, 165-172.

Amri, A., Bird, D. K., Ronan, K., Haynes, K., \& Towers, B. (2017). Disaster risk reduction education in Indonesia: Challenges and recommendations for scaling up. Natural Hazards and Earth System Sciences, 17, 595-612.

Avraham, M. (2006, October). Cross-disciplinary theories for cross-disciplinary teaching. Retrieved from CTDL Brief: http://www.cdtl.nus.edu.sg/brief/v9n5/sec3.htm

Beckett, G. H., \& Slater, T. (2018). Project-based learning and technology. In J. I. Liontas, The TESOL Encyclopedia of English Language Teaching (pp. 1-7). John Wiley \& Sons.

Brooks, M. (2009). Drawing, visualisation and young children's exploration of "big ideas". International Journal of Science Education, 31(3), 319-341.

Coates, E. (2002). 'I forgot the sky!' Children's stories contained within their drawings. International Journal of Early Years Education, 10(1), 21-35.

\section{CONCLUSION}


Donaghy, K. (2014, October 21). How can film help you teach and learn English? British Council.

Evans, C. (2006). Using TV news to integrate the four skills: A guide for EFL teachers. Brattelboro School for International Training.

Grapin, S. (2019). Multimodality in the new content standards era: Implications for English learners. TESOL Quarterly, 53(1), 30-55.

Haring, U., Sorin, R., \& Caltabiano, N. (2018). Circling the cyclone: Children's understanding of natural disasters through the Arts. The International Journal of Pedagogy and Curriculum, 25(4), 115.

Kousky, C. (2016). Impacts of natural disasters on children. The Future of Children, 26(1), 73-92.

Krajcik, J. S., \& Blumenfeld, P. C. (2012). Projectbased learning. In R. K. Sawyer, The Cambridge Handbook of the Learning Sciences (pp. 317334). Cambridge University Press. doi:http://dx.doi.org/10.1017/CBO978051181683 3

Kusumastuti, R., Viverita, V., Husodo, Z., Suardi, L., \& Danarsari, D. (2014). Developing a resilience index towards natural disasters in Indonesia. International Journal of Disaster Risk Reduction, 10, 327-340. doi:https://doi.org/10.1016/j.jjdrr.2014.10.007

Lee, E., \& Lee, H. (2019). Disaster awareness and coping: Impact on stress, anxiety and depression. Perspectives in Psychiatric Care, 55, 311-318. doi: $10.1111 /$ ppc. 12351

Lee, I. (2005). The implementation of project-based learning: A study in two Hong Kong secondary classrooms. The journal of ASIA TEFL, 2(1), 2154.

Mali, Y. C. (2017). EFL students' experiences in learning CALL through project based instruction. TEFLIN Journal, 28(2), 170-192. doi:http://dx.doi.org/10.15639/teflinjournal.v28i2/1 70-192

Marwan, A. (2015). Empowering English through Project-Based Learning with ICT. Turkish Online Journal of Educational Technology, 14(4), 28-37.

Moglen, D. (2014). Tuning in: Using the news for a content-based ESL class. The Catesol Journal, 26(1), 29-36.

Mufit, F., Asrizal, A., Hanum, S. A., \& Fadhilah, A. (2020). Preliminary research in the development of physics teaching materials that integrate new literacy and disaster literacy. IOP Conf. Series: Journal of Physics: Conf. Series 1481 (pp. 1-12). IOP Publishing.

Mustadi, A., \& Atmojo, S. E. (2020). Student's disaster literation in 'SETS' (science environment technology and society) disaster learning. Ilkogretim Online - Elementary Education Online, 19(2), 667-678.

Penttilä, T., Kairisto-Mertanen, L., \& Väänänen, M. (2014). Implementing cross-disciplinary learning environment: Benefits and challenges in engineering education. ICEE/ICIT 2014 Conference Proceedings, 428-431.

Richards, J. C. \& Rodgers, T. S. (2014). Approaches and Methods in Language Teaching. Cambridge University Press.

Sarıçoban, A., \& Yürük, N. (2016). The use of films as a multimodal way to improve learners' comprehension skills in reading in English Language and Literature Department at Selçuk. Turkish Online Journal of English Language Teaching, 1(3), 109-118.

Seyle, D. C., Widyatmoko, C. S., \& Silver, R. C. (2013). Coping with natural disasters in Yogyakarta, Indonesia: A study of elementary school teachers. Social Psychology International, 34(4), 387-404. doi:10.1177/0143034312446889

Siagian, T. H., Purhadi, P., Suhartono, S., \& Ritonga, H. (2014). Social vulnerability to natural hazards in Indonesia: Driving factors and policy implications. Natural Hazards, 70(2), 1603-1617. doi:https://doi.org/10.1007/s11069-013-0888-3

Szostak, R. (2015). Defining "multidisciplinary" and "cross-disciplinary". University of AlbertaDepartment of Economics.

Sözcü, U. (2020). Natural Disaster Literacy Curriculum Proposal. Journal of Disaster and Risk, 3(1), 7079.

Vygotsky, L. (1986). Thought and Language. (A. Kozulin, Trans.) MIT Press. 